\title{
SIMULTANEOUS ESTIMATION OF ESOMEPRAZOLE AND LEVOSULPIRIDE IN BULK AND IN CAPSULE FORMULATION BY RP-HPLC
}

\author{
RAKESH R. JAIN, PRAVIN O. PATIL*, SANJAY B. BARI
}

\begin{abstract}
Department of Quality Assurance, H.R. Patel Institute of Pharmaceutical Education and Research, Shirpur, Dist: Dhule (M.S.) India 425405
H. R. Patel Institute of Pharmaceutical Education and Research, Shirpur Dist: Dhule (M.S.) 425405 India
\end{abstract}

(Received: August 6, 2012 - Accepted: March 22, 2013)

\begin{abstract}
The present work deals with development and validation for simultaneous determination of Esomeprazole and Levosulpiride drugs in pharmaceutical formulations. A rapid, precise and specific reverse phase high performance liquid chromatography (RP-HPLC) method was developed for Esomeprazole and Levosulpiride. Chromatographic separations was achieved on a C-18 $(5 \mu \mathrm{m}, 250 \times 4.6 \mathrm{~mm})$ HPLC column within a runtime of 10 min. Isocratic mobile phase contain methanol: buffer $(\mathrm{pH} 3)(65: 35 \% \mathrm{v} / \mathrm{v})$ and flow rate was maintained at $1.0 \mathrm{~mL} / \mathrm{min}$. Eluate was monitored at $260 \mathrm{~nm}$. Levosulpiride was eluated at 2.7 $\mathrm{min}$ and Esomeprazole at $5.7 \mathrm{~min}$. Linearity was studied in the concentratiosn range of 5 to $30 \mu \mathrm{g} \mathrm{mL}-1$ and 10 to $60 \mu \mathrm{g} / \mathrm{mL}$ for esomeprazole and levosulpiride respectively, with a correlation coefficient of 0.9995 and 0.9993 respectively. The method was validated according to the ICH guidelines with respect to specificity, linearity, accuracy, precision and robustness.
\end{abstract}

Keywords: RP-HPLC, Esomeprazole, Levosulpiride, Capsule Formulation, Validation.

\section{INTRODUCTION}

Esomeprazole (ESO) chemically bis (5-methoxy-2-[-(s)-[(4-methaoxy3,5-dimethyl- 2- pyridinyl) methyl] sulfinyl]-1H-benzimidazole) [1]. The first single optical isomer ESO is a proton pump inhibitor, used for shortterm treatment of erosion and ulceratiosn of the esophagus caused by gastroesophageal reflux disorders. It has a favorable pharmacokinetics profile relative to omeprazole. Levosulpiride (LEVO) is levo-enatiomer of racemic sulpiride, 5- (aminosulfonyl) N-[(1-ethyl- 2 - pyrrolidinyl ) methyl ] 2 methoxy benzamide. Levosulpiride is most widely used drug in the treatment of depression, schizophrenia [2]. At low doses, LEVO increases dopaminergic neurotransmission, primarily by the blocking of the dopamine auto receptors, which inhibits the pre-synaptic dopamine synthesis and release of dopamine. Compared with racemic and dextro-forms, the levo-form of sulpiride has greater central antidopaminergic activity, antiemetic and antidyspeptic effects and lower acute toxicity [3].

The literature revealed, a number of analytical methods were reported for estimation of ESO including UV spectrophotometric and HPLC [4-9]. While estimation of LEVO was reported using HPLC and HPTLC [2] and Tandem mass spectrometry [10]. The RP-HPLC [11] and UV-Spectrophotometric [12] method have been studied for determination of LEVO and ESO in bulk and in pharmaceutical formulations. In present work, a successful attempt has been made to estimate both drugs simultaneously in capsule dosage form by RP-HPLC method. The chemical structures of both drugs are as shown in (Figures 1,2).

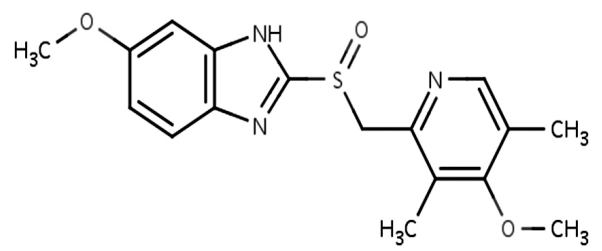

Figure 1: Chemical structure of Esomeprazole (ESO).<smiles>CCN1CCC[C@H]1CNC(=O)c1cc(S(N)(=O)=O)ccc1OC</smiles>

Figure 2: Chemical structure of Levosulpiride (LEVO).

\section{EXPERIMENTAL}

\section{Chemicals and Reagents}

HPLC grade methanol and analytical grade ortho-phosphoric acid were procured from Merck ${ }^{\circledR}$ India Ltd. (Mumbai). Water was purified with Milli-Q Millipore system. All the solvents and solutions were filtered through a membrane filter (Millipore filter paper, $0.45 \mu \mathrm{m}$ pore size) and degassed before use. Drug formulation (capsule) Sompraz ${ }^{\mathbb{R}} \mathrm{L}$ with label claim $40 \mathrm{mg}$ Esomeprazole and $75 \mathrm{mg}$ Levosulpiride was purchased from Indian market and used for estimation.

\section{Instrumentation and Materials}

Analysis was performed on Agilent HPLC 1200 series separations module with in-built PDA detector. Chromatographic software Ezechrome Elite was used for data collection and processing. The analytical column was LC-GC Qualisil BDS C18 (5 mm, $250 \mathrm{~mm} \mathrm{C} 4.6 \mathrm{~mm}$ ).

\section{Chromatographic Conditions}

Chromatographic separation and of ESO and LEVO were performed by use of an isocratic mobile phase prepared from 65:35 $(v / v)$ methanol: buffer $\left(10 \mathrm{mM}, \mathrm{KH}_{2} \mathrm{PO}_{4}\right), \mathrm{pH} 3$ (adjusted with ortho phosphoric acid) giving well resolved, sharp peak for LEVO and ESO with a retention time (tR) 2.7 and 5.7 $\mathrm{min}$. (Figure 3). The flow rate was maintained at $1.0 \mathrm{~mL} / \mathrm{min}$, UV detection was performed at $260 \mathrm{~nm}$ and ambient temperature $\left(25^{\circ} \mathrm{C}\right)$ for column oven was found to be the best for analysis.

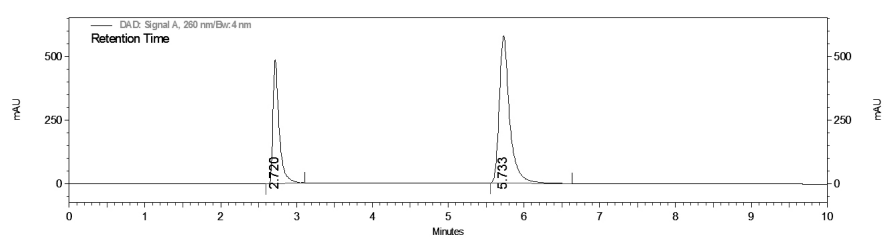

Figure 3: Typical chromatogram of LEVO and ESO.

Stock Solutions

Independent stock solution of $100 \mu \mathrm{g} / \mathrm{mL}$ of each ESO and LEVO were prepared in mobile phase.

\section{Analysis of the capsule dosage form:}

Twenty capsules (Sompraz ${ }^{\mathbb{R}} \mathrm{L}$ containing $40 \mathrm{mg}$ of ESO and $75 \mathrm{mg}$ of LEVO) were weighed accurately and crushed to form fine powder. Powder weight equivalent to $10 \mathrm{mg}$ of drug containing ESO and LEVO were dissolved in a $100 \mathrm{~mL}$ volumetric flask with methanol. It was sonicated followed by filtration through Whatmann filter paper (No. 41). Appropriate volumes of the aliquot were transferred into two set of six different $10 \mathrm{~mL}$ volumetric flasks and the volume was made up to the mark with mobile phase to get a 
concentrations of $15 \mu \mathrm{g} / \mathrm{mL}$ of ESO and $30 \mu \mathrm{g} / \mathrm{mL}$ of LEVO respectively. The solutions were subject to analysis and results obtained as in Table I.

Table I: Assay of ESO and LEVO capsule formulation.

\begin{tabular}{|c|c|c|c|}
\hline $\begin{array}{c}\text { Amount taken in } \\
{[\boldsymbol{\mu} \mathbf{g} / \mathbf{m L}]}\end{array}$ & $\begin{array}{c}\text { Amount found } \\
{[\boldsymbol{\mu g} / \mathbf{m L}] \text { Mean }}\end{array}$ & $\begin{array}{c}\text { \% Amount } \\
\text { Found }\end{array}$ & \% RSD \\
\hline 15 & 15.08 & 100.55 & 0.58 \\
\hline 30 & 30.13 & 100.44 & 0.93 \\
\hline${ }^{*} \mathrm{n}=6$
\end{tabular}

\section{Validation Parameters}

The developed method was validated as per ICH guidelines in terms of its linearity, accuracy, Limit of detection (LOD), Limit of quantification (LOQ), specificity, intra-day and inter-day precision and repeatability of measurement [13].

\section{Linearity}

Appropriate aliquots of standard stock solution were taken in different 10 $\mathrm{mL}$ volumetric flasks and diluted up to the mark with mobile phase to obtain final concentrations of $5,10,15,20,25$ and $30 \mu \mathrm{g} / \mathrm{mL}$ of ESO and 10, 20, $30,40,50$, and $60 \mu \mathrm{g} / \mathrm{mL}$ for LEVO. The solutions were injected using a 20 $\mu \mathrm{L}$ fixed loop system and chromatograms were recorded. ESO follow linearity between 5 to $30 \mu \mathrm{g} / \mathrm{mL}$ and LEVO between 10 and $60 \mu \mathrm{g} / \mathrm{mL}$. Results are tabulated in Table II.

Table II: Linearity data for ESO and LEVO.

\begin{tabular}{|c|cc|}
\hline Parameters & ESO $^{*}$ & LEVO $^{*}$ \\
\hline Linear range $(\mu \mathrm{g} / \mathrm{mL})$ & $5-30$ & $10-60$ \\
\hline Slope & 61262 & 12896 \\
\hline Intercept & 4740 & 12001 \\
\hline Correlation coefficient $\left(\mathrm{r}^{2}\right)$ & 0.9996 & 0.9993 \\
\hline
\end{tabular}

*Mean of six determinations.

\section{Accuracy}

Accuracy was found by studying level of recovery using standard addition method. Known amounts of standards of LEVO and ESO was added to preanalyzed samples at a level from $80 \%$ to $120 \%$ and then subjected to the proposed RP-HPLC method.

The solutions were then analyzed, and the percentage recoveries were calculated by using formula.

$\%$ Recovery $=\frac{\text { Found analyte mass }}{- \text { Added analyte mass }} \times 100$

Results obtained are tabulated in Table III.

Table III: Accuracy study of ESO and LEVO by RP-HPLC method.

\begin{tabular}{|c|c|c|c|}
\hline Level of recovery & $\begin{array}{c}\text { Amount of } \\
\mathbf{d r u g} \\
\text { added }(\boldsymbol{\mu g} / \mathbf{m L})\end{array}$ & \% Recovery* & \% RSD \\
\hline $80 \%$ & 12 & 99.33 & 1.28 \\
\hline ESO $\quad 100 \%$ & 15 & 99.38 & 0.78 \\
\hline $120 \%$ & 18 & 100.38 & 1.19 \\
\hline $80 \%$ & 24 & 100.85 & 0.49 \\
\hline LEVO $100 \%$ & 30 & 101.28 & 0.87 \\
\hline $120 \%$ & 36 & 99.47 & 0.62 \\
\hline
\end{tabular}

$*_{n}=6$

\section{Precision}

Intraday and interday precision of the assay samples containing ESO having concentratiosns of $15,20,25 \mu \mathrm{g} / \mathrm{mL}$ and LEVO having concentrations of $30,40,50 \mu \mathrm{g} / \mathrm{mL}$ were analyzed three times in the same day (intraday) and for three consecutive days (interday). Precision was calculated as intra and interday coefficient of variation $[\%$ C.V. = (S. D. /mean) $x 100]$ as shown in the Table IV.

Table IV: Precision data of ESO and LEVO by RP-HPLC.

\begin{tabular}{|c|c|c|c|c|}
\hline \multirow{2}{*}{$\begin{array}{c}\text { Conc. } \\
{\left[\boldsymbol{\mu g} / \mathbf{m L}^{-1}\right]}\end{array}$} & \multicolumn{2}{|c|}{$\begin{array}{c}\text { Intra-day } \\
\text { Amount found } \\
{[\boldsymbol{\mu g} / \mathbf{m L}]}\end{array}$} & \multicolumn{2}{c|}{$\begin{array}{c}\text { Inter-day } \\
\text { Amount found } \\
{[\boldsymbol{\mu g} / \mathbf{m L}]}\end{array}$} \\
\cline { 2 - 5 } & Mean & \% RSD* & Mean & \% RSD* \\
\hline ESO 15 & 15.16 & 1.21 & 15.08 & 1.12 \\
\hline 20 & 20.12 & 1.35 & 20.24 & 1.39 \\
\hline 25 & 25.22 & 1.28 & 25.16 & 1.51 \\
\hline LEVO 30 & 30.13 & 1.45 & 30.30 & 1.27 \\
\hline 40 & 39.85 & 1.38 & 39.69 & 1.09 \\
\hline 50 & 49.85 & 1.42 & 50.30 & 1.25 \\
\hline
\end{tabular}

\section{Robustness}

Robustness studies are performed by introducing deliberately small changes in the mobile phase composition $( \pm 5 \mathrm{~mL})$, flow rate $\left( \pm 0.1 \mathrm{~mL} / \mathrm{min}^{-1}\right)$. Robustness of the proposed method is studied and results tabulated in Table $\mathbf{V}$.

\section{Limit of detection (LOD) and Limit of quantification (LOQ)}

The LOD and LOQ were calculated by using the equations LOD $=3.3 \times$ $\mathrm{N} / \mathrm{B}$ and $\mathrm{LOQ}=10 \times \mathrm{N} / \mathrm{B}$ where ' $\mathrm{N}$ ' is the standard deviation of the peak areas of the drug $(\mathrm{n}=3)$ and ' $\mathrm{B}$ ' is the slope of the corresponding calibration plot. The signal to noise ratios was determined. The LOD was regarded as the amount for which the signal to noise ratios was 3:1 and LOQ regarded as the amount for which the signal to noise ratios was 10:1.

\section{RESULTS AND DISCUSSION}

\section{Optimization of Mobile Phase}

A RP-HPLC method was developed for an accurate and reproducible method for esomeprazole and levosulpiride. The method development trials were carried out using different ratios of buffer, acetonitrile and methanol. The method development trial was carried out using Qualisil BDS C ${ }_{18}$ column (250 $\mathrm{mm} \times 4.6 \mathrm{~mm}, 5 \mu$ ), The mobile phase flow rate $1 \mathrm{~mL} / \mathrm{min}^{-1}$ was examined. The detection wavelength was $260 \mathrm{~nm}$. Diode array detector was used and from the overlain spectra a wavelength of $260 \mathrm{~nm}$ was selected for the estimation of both drugs simultaneously (Figure $2 \mathrm{E}$ ). With a view to separate both drugs simultaneously (Figure 4), various mobile phases consisting of methanol and buffer, acetonitrile and buffer were tried, but tailing and low resolution of the chromatogram was observed. In trial 1 , the mobile phase consisted of acetonitrile and $\mathrm{KH}_{2} \mathrm{PO}_{4}(10 \mathrm{mM})$ buffer in a ratios of $(80: 20)$ was tried and chromatogram obtained not showed a better resolution for both drugs. In trial 2 the, mobile phase consisted of methanol and $\mathrm{KH}_{2} \mathrm{PO}_{4}(10 \mathrm{mM})$ buffer in the ratios of (90:10) was attempted in this chromatogram obtained having the retention time between two separatiosn was very less. While in the trial 3 , the mobile phase consisted of methanol and $\mathrm{KH}_{2} \mathrm{PO}_{4}$ buffer in the ratios of (80:20) was utilized and chromatogram obtained still not showed an improved resolutions for both drugs. In trial 4 , the mobile phase consisted of methanol and $\mathrm{KH}_{2} \mathrm{PO}_{4}(10 \mathrm{mM})$ buffer in the ratios of $(65: 35)$ was endeavored, in this mobile phase the chromatogram obtained showed asymmetry within limit as well as retention time within runtime of $10 \mathrm{~min}$ (Table VI). In this mobile phase not only separation time between two peak but also theoretical plates was good and so it was used as optimized mobile phase for the estimation of ESO and LEO in capsule formulation. Therefore, mobile phase consisting of Methanol : $10 \mathrm{mM}$ potassium dihydrogen phosphate buffer $(\mathrm{pH} 3)$, in 65:35 giving well resolved, sharp peak for LEVO and ESO with a retention times of $2.7 \mathrm{~min}$ and $5.7 \mathrm{~min}$ respectively (Figure 3). The flow rate of $1.0 \mathrm{~mL} / \mathrm{min}^{-1}$ at $260 \mathrm{~nm}$ and ambient temperature $\left(25^{\circ} \mathrm{C}\right)$ for column oven was found to be the best for analysis. Methanol was used for separations in the proposed method is cheaper and less toxic as compare to acetonitrile and buffer was used in smaller amount as compare to reported method [11]. Selection of $\mathrm{pH}$ is on trail 
error basis we have got low tailing and good resolution at $\mathrm{pH} 3.0$ therefore we selected $\mathrm{pH} 3$ for further estimation of ESO and LEO. Detection at 260 $\mathrm{nm}$ was chosen for determination of both drugs because it is their isobestic point, having both equal absorbance at that wavelength. This is an advantage in comparison with the detection at $240 \mathrm{~nm}$ [11], because at the latter wavelength the molar absorptivity of ESO is less than for LEVO, increasing the uncertainty for the quantification of ESO (Figure 4). The amount of both drugs quantified in formulation was better optimized in our method as compare to reported method [11]. The assay $\%$ of both drugs obtained was within a pharmacopeial limit, means recovery of drugs from tablet formulation was better and recovery was consistent because series of six results were in good agreement with the label claim. The \% RSD less than 2 indicates less error in the showed that proposed method is precise over reported methods. The $\%$ RSD was less than 2 in intraday, interday precision and all parameters of robustness are within limit. So the proposed method is more precise, accurate and robust Table VII. System suitability parameters were studied by injecting the working standard solution $(15 \mu \mathrm{g} / \mathrm{ml}$ of ESO and $30 \mu \mathrm{g} / \mathrm{ml}$ of LEVO), Table VIII.

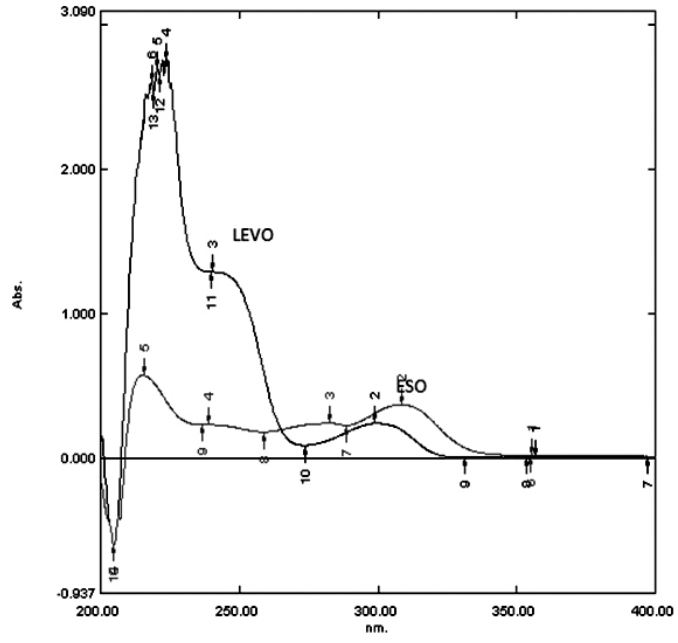

Figure 4 An overlain spectra of ESO and LEVO in methanol.

Table V: Robustness Studies.

\begin{tabular}{|c|c|c|c|c|}
\hline \multicolumn{2}{|c|}{ Chromatographic Conditions } & $\begin{array}{c}\text { Retention Time } \\
\text { tR }\end{array}$ & Tailing factor & Theoretical Plates \\
\hline \multicolumn{5}{|c|}{ A: Flow rate $(\mathrm{mL} / \mathrm{min})$} \\
\hline ESO & 0.9 & 6.60 & 1.50 & 10021 \\
\hline \multicolumn{2}{|c|}{1.0} & 5.73 & 1.40 & 11121 \\
\hline \multicolumn{2}{|c|}{1.1} & 5.40 & 1.54 & 10896 \\
\hline LEVO & 0.9 & 3.03 & 1.42 & 6296 \\
\hline \multicolumn{2}{|c|}{1.0} & 2.72 & 1.41 & 6590 \\
\hline \multicolumn{2}{|c|}{1.1} & 2.46 & 1.48 & 6125 \\
\hline $\mathrm{ESO} / \mathrm{LEVO}$ & Mean & $5.90 / 2.74$ & $1.48 / 1.44$ & $10679 / 6337$ \\
\hline \multicolumn{5}{|c|}{ B: Change in mobile phase composition } \\
\hline \multicolumn{2}{|c|}{$\begin{array}{l}\text { (methanol: buffer } 60: 40 v / v) \\
\text { ESO (methanol: buffer 65:35 v/v) } \\
\text { (methanol: buffer } 70: 30 v / v)\end{array}$} & $\begin{array}{l}6.30 \\
5.73 \\
4.90\end{array}$ & $\begin{array}{l}1.75 \\
1.48 \\
1.54\end{array}$ & $\begin{array}{l}10240 \\
12256 \\
11248\end{array}$ \\
\hline \multicolumn{2}{|c|}{$\begin{array}{l}\text { (methanol: buffer } 60: 40 v / v) \\
\text { LEVO } \\
\text { (methanol: buffer 65:35 v/v) }\end{array}$} & $\begin{array}{l}2.71 \\
2.73 \\
2.72\end{array}$ & $\begin{array}{l}1.64 \\
1.32 \\
1.38\end{array}$ & $\begin{array}{l}5142 \\
6027 \\
5928\end{array}$ \\
\hline ESO/ LEVO & Mean & $5.64 / 2.72$ & $1.59 / 1.44$ & $11248 / 5699$ \\
\hline
\end{tabular}

Table VI: Mobile phase optimization trials.

\begin{tabular}{|c|c|c|c|c|c|c|c|}
\hline \multirow{2}{*}{ Trials No. } & \multirow{2}{*}{$\begin{array}{l}\text { Mobile phase } \\
\text { Compostion }\end{array}$} & \multicolumn{2}{|c|}{$\begin{array}{c}\text { Retention Time } \\
\text { tR }\end{array}$} & \multicolumn{2}{|c|}{ Theoretical plates (USP) } & \multicolumn{2}{|c|}{$\begin{array}{c}\text { Asymmetry } \\
(10 \%)\end{array}$} \\
\hline & & ESO & LEVO & ESO & LEVO & ESO & LEVO \\
\hline 1 & $\begin{array}{c}\text { Acetonitrile : } 25 \mathrm{mM} \mathrm{KH}_{2} \mathrm{PO}_{4} \\
(10 \mathrm{mM}) \\
(\mathrm{pH} \mathrm{3.0)(80:20)}\end{array}$ & 5.98 & 2.19 & 10455 & 5794 & 1.46 & 1.24 \\
\hline 2 & $\begin{array}{c}\text { Methanol : } 10 \mathrm{mM} \mathrm{KH}_{2} \mathrm{PO}_{4} \\
(10 \mathrm{mM}) \\
(\mathrm{pH} 3.0)(90: 10)\end{array}$ & 3.62 & 2.68 & 7424 & 3729 & 1.53 & 1.08 \\
\hline 3 & $\begin{array}{l}\text { Methanol : } 10 \mathrm{mM} \mathrm{KH}_{2} \mathrm{PO}_{4} \\
(\mathrm{pH} 3.0)(80: 20)\end{array}$ & 4.02 & 2.66 & 5358 & 1575 & 1.34 & 0.91 \\
\hline 4 & $\begin{array}{c}\text { Methanol : } 10 \mathrm{mM} \mathrm{KH}_{2} \mathrm{PO}_{4} \\
(10 \mathrm{mM}) \\
(\mathrm{pH} 3.0)(65: 35)\end{array}$ & 5.73 & 2.72 & 11121 & 6590 & 1.40 & 1.43 \\
\hline
\end{tabular}


Table VII Summary of validation parameters.

\begin{tabular}{|ll|c|}
\hline Parameters & ESO & LEVO \\
\hline Linear range $\left(\mu \mathrm{g} / \mathrm{mL}^{-1}\right)[\mathrm{n}=6]$ & $5-30$ & $10-60$ \\
\hline Correlation coefficient $\left(\mathrm{r}^{2}\right)$ & 0.9996 & 0.9993 \\
\hline Limit of detection $\left(\mu \mathrm{g} / \mathrm{mL}^{-1}\right)$ & 0.36 & 0.45 \\
\hline Limit of quantification $\left(\mu \mathrm{g} / \mathrm{mL}^{-1}\right)$ & 1.09 & 1.39 \\
\hline$\%$ Recovery $[\mathrm{n}=3]$ & $99.33-100.38$ & $99.47-101.28$ \\
\hline Precision $[\% \mathrm{RSD}]$ & & 1.42 \\
\hline Intra-day $[\mathrm{n}=3]$ & 1.28 & 1.20 \\
\hline Inter-day $[\mathrm{n}=3]$ & 1.34 & 0.92 \\
\hline Repeatability $[\mathrm{n}=6]$ & 0.78 & Robust \\
\hline Robustness & & \\
\hline
\end{tabular}

Table VIII: System suitability parameters.

\begin{tabular}{|lc|c|c|}
\hline Parameters & ESO & LEVO & Acceptance criteria \\
\hline Theoretical plate & 12483 & 6007 & More than 2000 \\
\hline USP Tailing factor & 1.34 & 1.42 & Less than 2 \\
\hline Capacity factor & 31.0 & 66.45 & Should be non zero \\
\hline USP Resolution & 16.25 & - & More than 2 \\
\hline
\end{tabular}

\section{CONCLUSION}

The developed RP-HPLC method is simple, precise, accurate, selective and reproducible. The method has been found to be adequately rugged and robust and can be used for simultaneous determination of esomeprazole and levosulpiride in capsule formulation. The method was validated as per ICH guidelines.

\section{ACKNOWLEDGMENTS}

Authors acknowledge the support from management authorities of the H. R. Patel Institute of Pharmaceutical Education and Research, Shirpur (Maharashtra).

\section{REFERENCES}

1. Indian Pharmacopoeia, 2, 1295, (2010)

2. I B. Paek, Y. Moon, H. Y. Ji, H. H. Kim, H.W. Lee, Y. B. Lee, H. S. Lee, J. Chromatography B. 809, 345, (2004)

3. S. Manjunath, V. Chouhan, S. Sandeep, Int. J. Pharm. Pharma. Sci. 3(2), $135,(2011)$

4. D. G. Maheshwari, P. D. Trivedi, Int. J. App. Sci. and Eng. 9(3), 187, (2011)

5. R. K. Patel, B. P. Raval, B. H. Patel, L. J. Patel, Der. Pharma. Chemica. $2(1), 251,(2010)$

6. R. S. Reddy, S. Sait, G.Vasudevmurthy, B.Vishwanath, Der. Pharma. Chemical. 3(6), 553, (2011)

7. G. G. Rathi, R. K. Singh, P. S. Patel, R. K. Singh, B. Kumar, Int. J. Pharm. Sci. Res. 1 (6), 75, (2010)

8. M. C. Sharma, S. Sharma, J. Iran. Chem. Soc. 4, 25, (2011)
9. S. S. Patil, P. N. Dhabale, B. S. Kuchekar, Asian J.Res.Chem. 2(2), 154, (2009)

10. I. A. Naguib, M. Abdelkawy, Eur. J. Med. Chem. 45, 3719, (2010)

11. H. Patel, A. K. Shrivastava, D. Jindal, International Journal for Pharmaceutical Research Scholars.1(3), 1, (2012)

12. Y. P. Agrawal, S. P. Gautam, A. Verma, M. Y. Agrawal, A. K. Gupta, Der. Pharmacia. Sinica. 3 (3), 337,(2012)

13. ICH (1996) Harmonized tripartite guideline: validation of analytical procedures.Q2A 